\title{
Circadian variation of lymphocyte subpopulations: a study with monoclonal antibodies
}

\author{
ALASTAIR W S RITCHIE, IAN OSWALD, H SPEDDING MICKLEM, JANICE E BOYD, \\ ROBERT A ELTON, ELIZABETH JAZWINSKA, KEITH JAMES
}

\begin{abstract}
Use of monoclonal antibodies to identify subpopulations of circulating lymphocytes in healthy adults showed pronounced circadian variations in total $T$ cells, the two major $T$ cell subsets, and HLA-DR +1 ymphocytes. When the results for the $T$ cell subsets were expressed as a ratio (helper:suppressor) no significant rhythmic variation was observed. Lymphocytes bearing a surface antigen identified by the HNK-1 antibody (a population containing the natural killer and antibody dependent killer activity) did not show significant rhythmic variation. There was an inverse relation between plasma cortisol concentration and numbers of $T$ and $B$ cells.

These observations have therapeutic implications and should be considered in the course of immunological monitoring.
\end{abstract}

\section{Introduction}

Circadian variation of biological phenomena is often ignored by both doctors and scientists. In this report we describe wide circadian variation of some of the lymphocyte subsets, which

\footnotetext{
Department of Surgery, University Medical School, Edinburgh EH8 9AG

ALASTAIR W S RITCHIE, MB, FRCSED, research fellow

JANICE E BOYD, BSC, PHD, research fellow

KEITH JAMES, DSC, FRCPATH, reader

Department of Psychiatry, University of Edinburgh

IAN OSWALD, DSC, FRCPSYCH, professor

ELIZABETH JAZWINSKA, BSC, postgraduate student

Department of Zoology, University of Edinburgh

H SPEDDING MICKLEM, MA, DPHIL, reader
}

Medical Computing and Statistics Unit, University of Edinburgh ROBERT A ELTON, BA, PHD, lecturer

Correspondence to: $\mathrm{Mr}$ A W S Ritchie. play a part in the development and regulation of the immune response. This study was made possible by the development of a range of well characterised monoclonal antibodies, which in conjunction with flow cytometry permit rapid, precise enumeration of functionally distinct lymphocyte subpopulations. ${ }^{12}$ As a consequence of these technological developments lymphocyte subpopulations are under intensive study in a wide variety of diseases. For example, alterations of the relative proportions of the $T$ "helper" and $T$ "suppressor/cytotoxic" populations in peripheral blood of recipients of renal allografts correlate with rejection episodes. ${ }^{3}$ Since importance is being attached to relatively small changes in the ratio of $T$ helpers to suppressors we considered it important to establish a baseline by investigating physiological variation of the $T$ cell subsets and other subpopulations with a role in the immune response.

\begin{tabular}{ll} 
TABLE I-Panel of monoclonal antibodies used \\
\hline Monoclonal antibody & Cell population identified \\
\hline $\left.\begin{array}{l}\text { Anti-Leu-1 } \\
\text { Anti-Leu-4 }\end{array}\right\}$ & All T cells \\
Anti-Leu-3a & $\left.\begin{array}{l}\text { Helper subset of T cells } \\
\text { Anti-Leu-2a } \\
\text { Anti-Leu-2b }\end{array}\right\}$ \\
$\begin{array}{l}\text { Anti-HLA-DR } \\
\text { of T cells }\end{array}$ & $\begin{array}{l}\text { B cells and activated T } \\
\text { cells (monocytes*) }\end{array}$ \\
HNK-1 (Anti-Leu-7) & NK and K cells \\
\hline
\end{tabular}
* Monocytes were excluded from analysis using $90^{\circ}$ light
scatter variables (see text).

\footnotetext{
Methods

Peripheral blood samples were obtained at intervals of three hours from 10 healthy volunteers (mean age 51, range 45-58). Within the constraints of the blood sampling the subjects performed normal daily activities. They slept in a sleep research laboratory, of which they all had previous experience.

Total and differential white cell counts were performed on each blood sample. Plasma was separated and stored frozen for subsequent analysis of cortisol concentrations. Mononuclear cells were isolated on Ficoll Hypaque and then reacted with a panel of monoclonal antibodies to lymphocyte surface antigens (table I). Mouse monoclonal antibodies
} 
were either conjugated with fluorescein isothiocyanate direct or were visualised with a second, antimouse antibody conjugated with fluorescein isothiocyanate. All analyses were performed on unfixed cell preparations with a fluorescence activated cell sorter (FACS IV, Becton Dickinson FACS Systems, Sunnyvale, California). Ten thousand cells were analysed for each antibody, the number of fluorescent cells being expressed as a percentage of the total lymphocytes. Non-lymphocytic cells contaminating the preparations were excluded from analysis using scatter gates set on the $90^{\circ}$ light scatter profile. $^{3 a}$ The proportions of cells that were fluorescent on analysis with the fluorescence activated cell sorter were used in conjunction with the total and differential white cell counts to calculate absolute numbers of cells in each subpopulation.

Statistical analyses of the percentages and absolute numbers of cells were performed using the methods of Nelson et al, ${ }^{4}$ which entailed fitting sine curves to the data from individual subjects and testing whether the variables of these curves showed consistent patterns of circadian variation.

\section{Results}

Variations of all the lymphocyte subpopulations were noted over 24 hours of study. The variations were significant $(p<0.05)$ for absolute numbers of $\mathrm{Leu}_{-1}^{+}, \mathrm{Leu}-4^{+}$(total $\mathrm{T}$ cells), Leu-3a ${ }^{+}$( $\mathrm{T}$ helper subset), Leu-2a $\mathrm{a}^{+}, \mathrm{Leu}-2 \mathrm{~b}^{+}$( $\mathrm{T}$ suppressor/cytotoxic subset), and HLA-DR ${ }^{+}$(B cells and activated $\mathrm{T}$ cells) lymphocytes. In contrast, HNK-1 $1^{+}$cells did not exhibit significant circadian variation. Figure 1 shows the variation in the Leu- $3 \mathrm{a}^{+}$subset of cells, with peak levels occurring at night. When expressed as percentages of the total number of lymphocytes Leu- $3 \mathrm{a}^{+}$and $\mathrm{HNK}-1^{+}$cells showed significant variation.

Plasma cortisol concentration showed the expected large amplitude rhythm and varied inversely with the numbers of $T$ and $B$ cells (fig 2).

The ratio of $T$ helper to suppressor cells (Leu-3a+ $:$ Leu- $2 b^{+}$) showed only minor variations over time and did not exhibit significant rhythmic variation.

Table II summarises the data for each subset.

\section{Discussion}

There is now considerable evidence that the magnitude of the immune response varies with the time of day. ${ }^{5}$ The findings of this study may in part explain the variations by demonstrating changes in the number of circulating cells available to encounter and process antigen.

Circadian variation of total lymphocytes, ${ }^{6}$ surface $\mathrm{Ig}^{+}$cells, ${ }^{7}$ and cells forming rosettes with sheep erythrocytes ${ }^{8}$ has been reported previously. Our use of monoclonal antibodies in

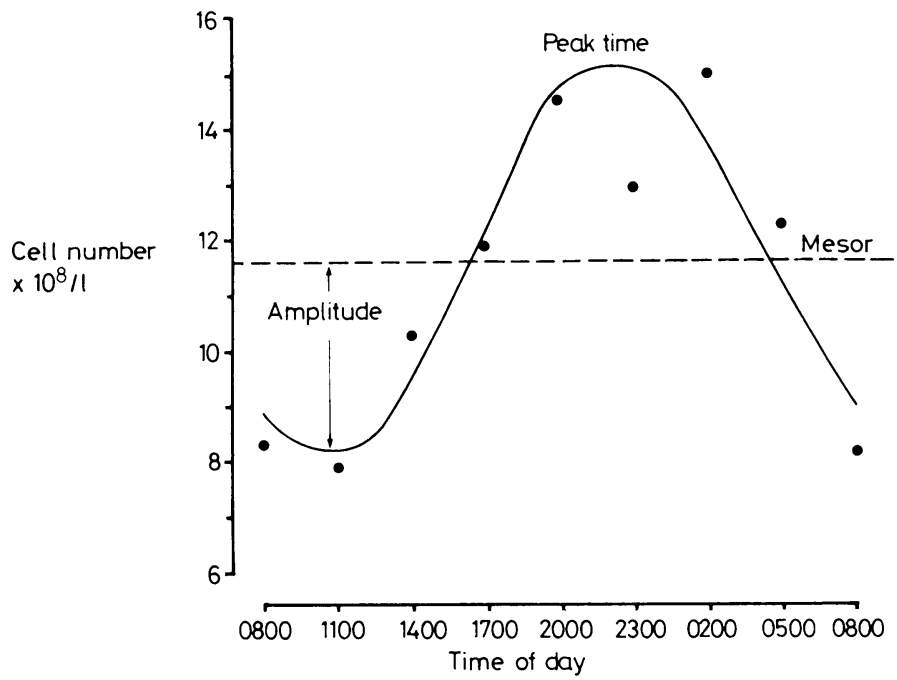

FIG 1-Circadian variation of Leu-3a ${ }^{+}$cells (helper subset of T cells). (Each point represents mean value in 10 subjects.) Mesor 11.66; peak time 2232 ; circadian variation $(2 \times$ amplitude $/$ mesor $)=59 \%$.

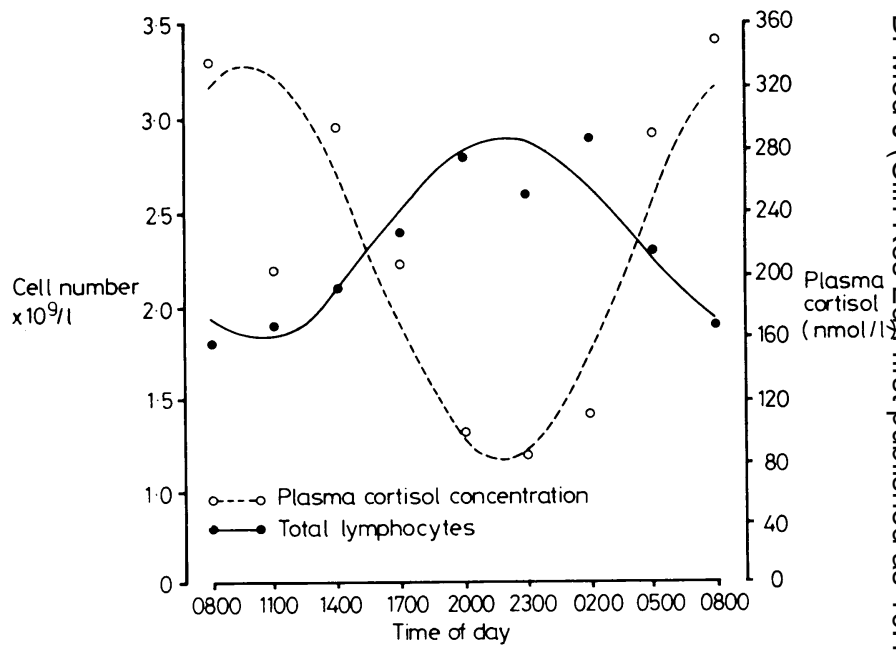

FIG 2-Comparison of circadian variations of total lymphocytes and plasma $\vec{\omega}$ cortisol concentration. (Each point represents mean value in 10 subjects.)

Conversion: SI to traditional units-Cortisol: $1 \mathrm{nmol} / 1 \approx 36 \cdot 3 \mathrm{ng} / 100 \mathrm{ml}$.

TABLE II-Circadian variation of lymphocyte subpopulations contrasted with plasma cortisol variation (data derived from best fitting sine curves)

\begin{tabular}{|c|c|c|c|c|c|}
\hline & Mesor & Amplitude & Peak time & $\begin{array}{c}\text { Circadian } \\
\text { variation }(\%)\end{array}$ & $\begin{array}{l}\text { Significance of } \\
\text { circadian rhythm }\end{array}$ \\
\hline \multicolumn{6}{|c|}{ Results expressed as absolute number of cells $\times 10^{*} / 1$} \\
\hline $\begin{array}{l}\text { Leu-4 } \\
\text { Leu-3a } \\
\text { Leu-2 }{ }^{+} \\
\text {HLA-DR } \\
\text { HNK-1 }\end{array}$ & $\begin{array}{r}16.0 \\
11.7 \\
4.3 \\
3.5 \\
2.5\end{array}$ & $\begin{array}{l}4 \cdot 3 \\
3 \cdot 4 \\
1 \cdot 0 \\
0 \cdot 9\end{array}$ & $\begin{array}{l}2222 \\
2232 \\
2156 \\
2305\end{array}$ & $\begin{array}{l}54 \\
59 \\
47 \\
53\end{array}$ & $\begin{array}{l}\mathrm{p}<0.05 \\
\mathrm{p}<0.001 \\
\mathrm{p}<0.05 \\
\mathrm{p}<0.05 \\
\text { NS }\end{array}$ \\
\hline \multicolumn{6}{|c|}{ Results expressed as percentage of total lymphocytes } \\
\hline $\begin{array}{l}\text { Leu-4 } \\
\text { Leu-3a } \\
\text { Leu-2 }{ }^{+} \\
\text {HLA-DR }{ }^{+} \\
\text {HNK-1 }\end{array}$ & $\begin{array}{l}66 \cdot 2 \\
47 \cdot 4 \\
17 \cdot 9 \\
14 \cdot 5 \\
11 \cdot 0\end{array}$ & $5 \cdot 1$ & 2339 & 22 & $\begin{array}{l}\text { NS } \\
\mathrm{p}<0.05 \\
\mathrm{NS} \\
\mathrm{NS} \\
\mathrm{p}<0.01\end{array}$ \\
\hline $\begin{array}{l}\text { Helper: } \\
\text { suppressor } \\
\text { ratio } \\
\text { Plasma }\end{array}$ & $2 \cdot 6$ & & Other resu & & NS \\
\hline $\begin{array}{l}\text { cortisol } \\
(\mathrm{nmol} / \mathrm{l})\end{array}$ & 208 & 126 & 0948 & 121 & $\mathrm{p}<0.01$ \\
\hline
\end{tabular}

Conversion: SI to traditional units-Cortisol: $1 \mathrm{nmol} / 1 \approx 36 \cdot 3 \mathrm{ng} / 100 \mathrm{ml}$.

conjunction with flow cytometry permitted further subclassification of the lymphocyte population and greater precision ino enumeration. It would have been impossible to analyse this number of samples and to count the cells in each sample by lighto or fluorescent microscopy. The development ${ }^{9}$ and characterisa- $₹$ tion $^{10-12}$ of the HNK-1 monoclonal antibody enabled us to응 identify cells with NK and K cell function by surface labelling without the necessity for time consuming functional assays.

The variation of numbers of circulating $B$ and $T$ cells pointso to sizable shifts of cells into and out of the circulation. The traffic of cells through other lymphoid tissue, including boneo marrow, may allow for contact between antigen primed regula- $\omega$ tory $\mathrm{T}$ cells and $\mathrm{B}$ cells. The lack of variation of $\mathrm{HNK}-1^{+}$cells correlates with the fact that only $0.7 \%$ of nucleated bone marrowe cells have this phenotype. ${ }^{10}$ It also correlates with the finding that in lymphoid tissues $\mathrm{HNK}-1^{+}$cells are predominantly ${ }^{+}$ located within germinal centres, ${ }^{12}$ which are not regarded as part of the lymphocyte recirculation pathway. ${ }^{13}$

The striking inverse relation of the numbers of circulating $\mathrm{T}$ and $\mathrm{B}$ cells and plasma cortisol concentration, in conjunction with the reported $\mathrm{T}$ lymphopenia in patients with Cushing' syndrome $^{14}$ and transient lymphopenia after single doses of exogenous corticosteroid, ${ }^{15}{ }^{16}$ suggest a causal interrelation.

The results have certain clinical implications. For example would the efficiency of antilymphocyte chemotherapy be् improved if administration was timed to produce peak plasma 
concentrations when the maximum number of cells are in the circulation? Does rejection occur earlier if allografts are transplanted at night, when the number of $\mathrm{T}$ cells in the recipients' circulation are at their peak ? With respect to the last question, circadian variation in the rejection of rat renal allografts has been described, ${ }^{17}$ and the longest surviving grafts were those inserted when the numbers of circulating lymphocytes were at their trough. Sound data relating time of operation to onset of rejection, or graft survival, in man are lacking, although circadian variation in episodes of renal allograft rejection has been suggested. ${ }^{18}$

We have shown that in any attempt at immunological monitoring account must be taken of circadian variation of lymphocyte subpopulations as a source of variance in results. Conversely, we found the ratio of helper to suppressor cells to be fairly stable in our healthy subjects.

This study was supported by a grant from the Melville Trust. We thank Drs T Abo, C M Balch, and M D Cooper for the gift of the HNK-1 antibody; Professor G D Chisholm for discussion and encouragement; and Mr R A Gray for help with the fluorescence activated cell sorter analysis.

ADDENDUM-Six of the subjects were studied over a further 24 hour period, during which they were deprived of sleep. There were no significant differences in any of the rhythmic variations over this period when compared with the first set of data for these six subjects.

\section{References}

1 Reinherz EL, Schlossman SF. Regulation of the immune responseinducer and suppressor T lymphocyte subsets in human beings. $N$ Eng l f Med 1980;303:370-3.

Herzenberg LA, Herzenberg LA. Analysis and separation using the fluorescence activated cell sorter (FACS). In: Weir DM, ed. Handbook of experimental immunology. 3rd ed. London: Blackwell Scientific, 1978:22.1-22.21

${ }^{3}$ Cosimi AB, Colvin RB, Burton RC, et al. Use of monoclonal antibodies to
$\mathrm{T}$ cell subsets for immunologic monitoring and treatment in recipients of renal allografts. $N$ Engl f Med 1981 ;305:308-14.

3a Ritchie AWS, Gray RA, Micklem HS. Right angle light scatter: a necessary parameter in flow cytofluorimetric analysis of human peripheral blood mononuclear cells. F Immunol Methods (in press).

4 Nelson W, Tong YL, Halberg F. Methods for cosinorrhythmometry. Chronobiologia 1979;6:305-23.

${ }^{5}$ Pownall R, Knapp MS. Immune responses have rhythms: are they important? Immunology Today 1980 October: vii-x.

${ }^{6}$ Bartter FC, Delfa CS, Halberg F. A map of blood and urinary changes related to circadian variations in adrenal cortical function in normal subjects. Ann NY Acad Sci 1962;98:969-83.

${ }^{7}$ Abo T, Kumagi K. Surface studies of immunoglobulins on human B lymphocytes. III. Physiological variations of $\mathrm{SIg}^{+}$cells in peripheral blood. Clin Exp Immunol 1978;33:441-52.

* Abo T, Kawate T, Itoh $\mathrm{K}$, et al. Characterization of rhythms and cell components in circadian variations of human and mouse lymphocytes. Chronobiologia 1979;6:71-2.

9 Abo T, Balch CM. A differentiation antigen of human $\mathrm{NK}$ and $\mathrm{K}$ cells identified by a monoclonal antibody (HNK-1). F Immunol 1981;127: 1024-9.

${ }^{10}$ Abo T, Cooper MD, Balch CM. Characterization of HNK-1+ (Leu-7) human lymphocytes. I. Two distinct phenotypes of human NK cells with different cytotoxic capability. F Immunol 1982;129:1752-7.

11 Abo T, Balch CM. Characterization of HNK-1 + (Leu-7) human lymphocytes. II. Distinguishing phenotypic and functional properties of natural killer cells from activated NK-like cells. F Immunol 1982;129:1758-61.

12 Ritchie AWS, James $K$, Micklem HS. The distribution and possible significance of cells identified in human lymphoid tissue by the monoclonal antibody HNK-1. Clin Exp Immunol 1983;51:439-47.

${ }^{13}$ Ford WL. Lymphocyte migration and immune responses. Prog Allergy 1975;19:1-59.

14 Shohat B, Klein A, Kaufmann $\mathrm{H}$, et al. $\mathrm{T}$ lymphocytes and plasma inhibitory factor in ACTH-dependent Cushings patients. Fournal of Clinical Immunology and Immunopathology 1979;13:452-61.

15 Fauci AS, Dale DC. The effect of in vivo hydrocortisone on subpopulations of human lymphocytes. $\mathcal{f}$ Clin Invest 1974;53:240-6.

16 Yu DTY, Clements PJ, Paulus HE, et al. Human lymphocyte subpopulations: effect of corticosteroids. $\mathcal{F}$ Clin Invest 1974;53:565-71.

17 Ratte J, Halberg F, Kuhl JFW, et al. Circadian variation in the rejection of rat kidney allografts. Surgery 1973;73:102-8.

18 Knapp MS, Cove-Smith JR, Dugdale R, et al. Possible effect of time on renal allograft rejection. $\mathrm{Br}$ Med f 1979;i :75-7.

(Accepted 24 March 1983)

\title{
Renal transplantation in children with occult neurogenic bladders drained by intermittent self catheterisation
}

\author{
O H STANLEY, T L CHAMBERS, B D PENTLOW
}

\begin{abstract}
Children with neurogenic bladders have usually not been considered for renal transplantation because of the potential complications caused by chronic infections of the urinary tract. Two girls with occult neurogenic bladders who were practising intermittent self catheterisation were given renal transplants. Both took prophylactic antibacterial agents after transplantation, and both experienced infections at some stage, but none of these infections produced a deterioration in renal function. In one patient creatinine clearance fell and signs of
\end{abstract}

Regional Department of Paediatric Renal Dialysis and Transplantation, Southmead Hospital, Bristol BS10 5NB

O H STANLEY, MRCP, paediatric registrar

T L CHAMBERS, FRCP, consultant paediatrician

B D PENTLOW, FRCS, consultant transplant surgeon

Correspondence to: Dr T L Chambers. obstruction appeared, but this was because the patient had been catheterising herself only two or three times a week. When she resumed catheterisation four times a day creatinine clearance rose and the urographic and renographic appearances returned to normal.

These results suggest that, with adequate catheterisation and urinary chemoprophylaxis, infection is not a particular problem in children with bladder dysfunction who undergo renal transplantation.

\section{Introduction}

Intermittent clean self catheterisation is an accepted form of managing neurogenic bladders in childhood which does not produce major problems arising from sepsis. ${ }^{1}$ It might be supposed that the immunosuppression associated with renal transplantation would lead to problems with infection. We describe two children with occult neurogenic bladders who received renal transplants while practising intermittent self catheterisation after micturition. 